\title{
Successful ventilation of two animals with a single ventilator: individualized shared ventilator setup in an in vivo model
}

\author{
Michiel Stiers ${ }^{1 *}\left(\mathbb{D}\right.$, Tom Bleeser $^{2}$, Matthias Mergeay ${ }^{3}$, Hannah Pinson ${ }^{4}$, Luc Janssen $^{3}$ and Tom Schepens ${ }^{5}$
}

\section{Dear Editor,}

As the ongoing COVID-19 crisis is spreading from developed into developing nations, a shortage of ventilators in ICUs can be expected during peak prevalence. Sharing a ventilator among patients has been put forward as a rescue solution [1,2]; in this setting, the so-called pairing of patients with similar characteristics is needed [3-5]. We have developed a modified shared ventilator design that allows for individualization of tidal volumes and driving pressures, positive end-expiratory pressure (PEEP), and inspired oxygen fraction $\left(\mathrm{FiO}_{2}\right)$ [6], which can thus substantially individualize the delivered breaths, removing the need of pairing (see Fig. 1).

We have now successfully used this ventilator setup in an in vivo model in a pair of ventilated sheep with different lung compliance, further supporting the potential of this shared ventilator setup as a lifesaving intervention in a crisis setting.

After ethical approval, two healthy Swifter sheep $(62 \mathrm{~kg}$ and $60 \mathrm{~kg}$, 1 year old) received general anesthesia (buprenorphine-sevoflurane), intubation, arterial catheter, and a C-section. After baseline blood

* Correspondence: michielstiers@hotmail.com

${ }^{1}$ Department of Emergency Medicine, St-Dimpna, J-B Stessensstraat 2, 2440 Geel, Belgium

Full list of author information is available at the end of the article gas and respiratory mechanics measurements, both sheep were connected to a single ventilator. Animal 1 had a lung compliance of $38 \mathrm{ml} \mathrm{cmH}_{2} \mathrm{O}^{-1}$, while animal 2 had a lung compliance of $28 \mathrm{ml} \mathrm{cmH}_{2} \mathrm{O}^{-1}$, differences in compliance could be explained by their position. Ventilator settings and measurements are shown in Table 1 . The targeted tidal volume of the shared ventilator was set by adding together the individual tidal volumes of animal $1(600 \mathrm{ml})$ and $2(800$ $\mathrm{ml}$ ), creating a combined tidal of $1400 \mathrm{ml}$. We measured individual airway pressures, with a fluid-air interfaced pressure transducer (Edwards Lifesciences, Irvine, USA), and individual end-tidal $\mathrm{CO}_{2}\left(\right.$ etCO $\left.{ }_{2}\right)$ levels (see Fig. 1). We then partially closed the inspiratory flow for animal 1 until the measured et $\mathrm{CO}_{2}$ levels for each animal were similar to those measured at baseline. This titration was successfully achieved within a few breaths, and the total set tidal volume could be distributed accurately among the two animals. With the added in-line individual PEEP valve, animal 2 received a PEEP of $7 \mathrm{cmH}_{2} \mathrm{O}$, whereas the other received $3 \mathrm{cmH}_{2} \mathrm{O}$ of PEEP. The individually measured airway pressures demonstrated that the set PEEP levels were successfully achieved for each animal. $\mathrm{FiO}_{2}$ could be adjusted as expected, with one animal receiving an $\mathrm{FiO}_{2}$ of $\sim 0.3$ and the other $\sim 0.8$ with added $\mathrm{O}_{2}$ to its breathing circuit during a short test period. Adequacy of ventilation and oxygenation 


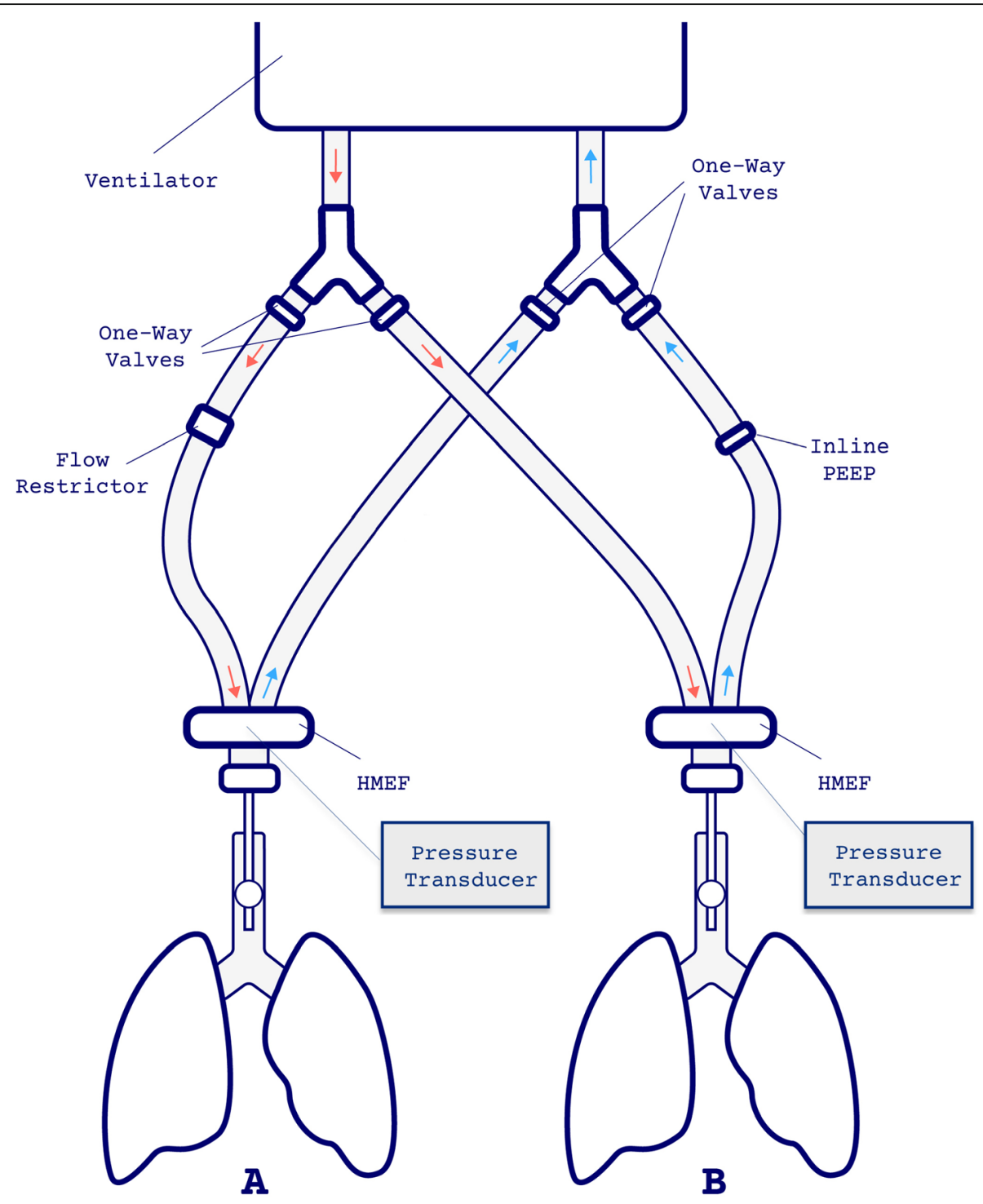

Fig. 1 Individualized shared ventilator setup in an in vivo model. The ventilator we used was a Datex Ohmeda s/5 Aespire, T-connectors split expiratory and inspiratory circuits. The rotatory valve (Sisto-16RGA) is placed in the inspiratory limb to restrict pressure and thus tidal volume to the subject with the highest lung compliance, and an in-line PEEP valve (Intersurgical, ref. 2207000) is added to the expiratory limb of the circuit to set PEEP individually. Side-stream supply of additional oxygen can modulate the $\mathrm{FiO}_{2}$ that is delivered to each patient. One-way valves (Intersurgical, ref. 1921000) prevent cross-contamination

in this setup was demonstrated with repeated blood gas measurements. Both $\mathrm{PaCO}_{2}, \mathrm{PaO}_{2}$, and $\mathrm{pH}$ values remained within normal range, thus we can assume that the individual tidal volumes before and after sharing the ventilator were similar. Hemodynamic parameters remained unchanged from baseline during the shared ventilator period. The animals were sacrificed after $3 \mathrm{~h}$ of mechanical ventilation.

We demonstrated the potential to modulate delivered tidal volumes and pressures, PEEP and $\mathrm{FiO}_{2}$ in a shared ventilator setup in this in vivo model. The added ventilator circuit modifications are inexpensive and readily available or can be $3 \mathrm{D}$-printed. This setup has allowed to safely ventilate a pair of animals with different lung compliance with a single ventilator, while monitoring and adjusting individual airway pressures and tidal volumes. However, I/E ratios and respiratory remain identical, and supplemental monitoring is required for safety reasons. We must stress that this setup is only to be used temporarily in a crisis setting while arranging for safer and more structural alternatives. The lung compliances were similar to what is frequently seen in ARDS. We think that this is a relevant step in the progressive development 
Table 1 Ventilator settings and measurements of in vivo individualized shared ventilation

\begin{tabular}{|c|c|c|c|c|}
\hline & \multicolumn{2}{|c|}{ Individual ventilation } & \multicolumn{2}{|c|}{ Shared ventilator } \\
\hline & Animal 1 & Animal 2 & Animal 1 & Animal 2 \\
\hline \multicolumn{5}{|l|}{ Ventilator settings } \\
\hline Tidal volume (ml) & 600 & 800 & 1400 & \\
\hline PEEP $\left(\mathrm{cmH}_{2} \mathrm{O}\right)$ & 3 & 4 & 3 & 7 \\
\hline $\mathrm{FiO}_{2}$ & 0.3 & 0.3 & 1.0 & \\
\hline I/E ratio & $1: 2$ & $1: 2$ & $1: 1.5$ & \\
\hline Respiratory rate $\left(\mathrm{min}^{-1}\right)$ & 20 & 20 & 20 & \\
\hline \multicolumn{5}{|l|}{ Measured ventilatory values } \\
\hline PEEP $\left(\mathrm{cmH}_{2} \mathrm{O}\right)$ & 3 & 5 & 4 & 7 \\
\hline Ppeak vent $\left(\mathrm{cmH}_{2} \mathrm{O}\right)$ & 18 & 32 & 31 & \\
\hline Ppeak circuit $\left(\mathrm{cmH}_{2} \mathrm{O}\right)$ & & & 19 & 18 \\
\hline $\mathrm{etCO}_{2}$ & 31 & 33 & 32 & 29 \\
\hline \multicolumn{5}{|l|}{ Blood gas values } \\
\hline $\mathrm{pH}$ & 7.54 & 7.54 & 7.47 & 7.49 \\
\hline $\mathrm{PaO}_{2}(\mathrm{mmHg})$ & 112 & 230 & 443 & 376 \\
\hline $\mathrm{PaCO}_{2}(\mathrm{mmHg})$ & 31 & 30 & 39 & 36 \\
\hline \multicolumn{5}{|l|}{ Hemodynamic values } \\
\hline $\mathrm{BP}(\mathrm{mmHg})$ & $76 / 43$ & $83 / 38$ & $73 / 40$ & $84 / 36$ \\
\hline
\end{tabular}

Table 1 shows the settings of the ventilator per animal and for the shared ventilator in a volume-controlled ventilation. In animal 2 , inline PEEP was applied; in animal 1, the flow restriction with our valve was applied to distribute the pressures as desired among the two animals.

of a shared ventilator solution, but further research needs to be done to better understand its full potential in treating patients with COVID-19.

\section{Abbreviations}

PEEP: Positive end-expiratory pressure; $\mathrm{FiO}_{2}$ : Inspiratory fraction of oxygen; I/ E: Inspiratory/expiratory time ratio; Ppeak: Peak pressure; vent: As measured by ventilator; Indiv: Individually measured on circuit; et $\mathrm{CO}_{2}$ : End-tidal carbon dioxide; $\mathrm{PaO}_{2}$ : Partial pressure of oxygen, arterial; $\mathrm{PaCO}_{2}$ : Partial pressure of $\mathrm{CO}_{2}$, arterial

\section{Acknowledgements}

We would like to thank Prof. Dr. Jan Deprest and his lab personnel in facilitating this experiment.

\section{Authors' contributions}

Authorship was based on the ICMJE guidelines. All authors contributed to the study conception and design. Material preparation were performed by MS, TB, MM, L, and TS. The data collection and analysis were performed by MS, MM, HP, LJ, and TS. The figure and tables were designed and edited by HP, MS, and TS. The first draft of the manuscript was written by TS and MS. All authors commented on previous versions of the manuscript. All authors read and approved the final manuscript.

\section{Funding}

The authors received no specific funding for this work. Hannah Pinson acknowledges a fellowship from the Research Foundation Flanders (FWO), under grant no. 11A6819N.

\section{Availability of data and materials}

All data generated or analyzed during this study are included in this published article and are shown in Table 1.

\section{Ethics approval and consent to participate}

Approval by the Ethics Committee for Animal Experimentation of the Animalium of KU Leuven, Belgium (P066/2020,) was obtained.

\section{Consent for publication}

Not applicable.

\section{Competing interests}

The authors declare that they have no competing interests.

\section{Author details}

${ }^{1}$ Department of Emergency Medicine, St-Dimpna, J-B Stessensstraat 2, 2440 Geel, Belgium. ${ }^{2}$ Department of Anesthesiology, UZ Leuven, Herestraat 49, 3000 Leuven, Belgium. ${ }^{3}$ Department of Anesthesiology and Critical Care Medicine, St-Dimpna, J-B Stessensstraat 2, 2440 Geel, Belgium. ${ }^{4}$ Applied Physics and Data Analytics, Vrije Universiteit Brussel, Pleinlaan 2, 1050 Brussels, Belgium. ${ }^{5}$ Department of Critical Care Medicine, Antwerp University Hospital, University of Antwerp, Wilrijkstraat 10, 2650 Edegem, Belgium.

Received: 6 June 2020 Accepted: 12 August 2020

Published online: 27 August 2020

\section{References}

1. Neyman G, Irvin CB. A single ventilator for multiple simulated patients to meet disaster surge. Acad Emerg Med. 2006;13(11):1246-9 [cited 2020 Mar 18]. Available from: http://doi.wiley.com/10.1197/j.aem.2006.05.009.

2. Paladino L, Silverberg M, Charchaflieh JG, Eason JK, Wright BJ, Palamidessi N, et al. Increasing ventilator surge capacity in disasters: ventilation of four adult-human-sized sheep on a single ventilator with a modified circuit. Resuscitation. 2008;77(1):121-6.

3. Pearson SD, Hall JB, Parker WF. Two for one with split- or co-ventilation at the peak of the Covid-19 tsunami: is there any role for communal care when the resources for personalised medicine are exhausted? Thorax. 2020; 75:444-5 BMJ Publishing Group.

4. Tonetti T, Zanella A, Pizzilli G, Irvin Babcock C, Venturi S, Nava S, et al. One ventilator for two patients: feasibility and considerations of a last resort solution in case of equipment shortage. Thorax. 2020;75(6):517-9.

5. Beitler J, et al. Ventilator sharing during an acute shortage caused by the COVID-19 pandemic. Am J Respir Crit Care Med. 2020. https://doi.org/10. 1164/rccm.202005-1586LE.

6. Stiers $M$, Mergeay $M$, Pinson $H$, Janssen $L$ et al. Individualized mechanical ventilation in a shared ventilator setting: limits, safety and technical details., 27 May 2020, PREPRINT (Version 1) available at Research Square [+ https:// doi.org/10.21203/rs.3.rs-31765/v1+ ].

\section{Publisher's Note}

Springer Nature remains neutral with regard to jurisdictional claims in published maps and institutional affiliations.
Ready to submit your research? Choose BMC and benefit from:

- fast, convenient online submission

- thorough peer review by experienced researchers in your field

- rapid publication on acceptance

- support for research data, including large and complex data types

- gold Open Access which fosters wider collaboration and increased citations

- maximum visibility for your research: over $100 \mathrm{M}$ website views per year

At BMC, research is always in progress.

Learn more biomedcentral.com/submission 